\title{
Demonstration of a Solution Film Leak Test Technique and Equipment for the S00645 Canister Closure
}

by

G. R. Cannell

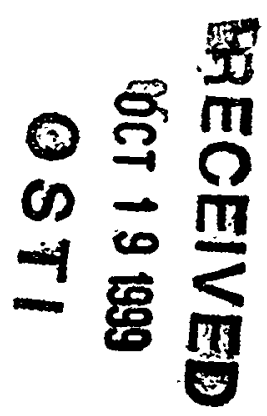

Westinghouse Savannah River Company

Savannah River Site

Aiken, South Carolina 29808

DOE Contract No. DE-AC09-96SR18500

This paper was prepared in connection with work done under the above contract number with the U.S.

Department of Energy. By acceptance of this paper, the publisher and/or recipient acknowledges the U.S.

Government's right to retain a nonexclusive, royalty-free license in and to any copyright covering this paper, along with the right to reproduce and to authorize others to reproduce all or part of the copyrighted paper. 


\section{DISCLAIMER}

This report was prepared as an account of work sponsored by an agency of the United States Government. Neither the United.States Government nor any agency thereof, nor any of their employees, makes any warranty, express or implied, or assumes any legal liability or responsibility for the accuracy, completeness, or usefulness of any information, apparatus, product, or process disclosed, or represents that its use would not infringe privately owned rights. Reference herein to any specific commercial product, process, or service by trade name, trademark, manufacturer, or otherwise does not necessarily constitute or imply its endorsement, recommendation, or favoring by the United States Government or any agency thereof. The views and opinions of authors expressed herein do not necessarily state or reflect those of the United States Government or any agency thereof.

This report has been reproduced directly from the best available copy.

Available to DOE and DOE contractors from the Office of Scientifis and Technical Information, P.O. Box 62, Oak Ridge, TN 37831; prices available from (615) 576-8401.

Available to the public from the National Technical Information Service, U.S. Department of Commerce, 5285 Port Royal Road, Springfield, VA 22161. 


\section{DISCLAIMER}

Portions of this document may be illegible in electronic image products. Images are produced from the best available original document. 
WSRC-TR-99-00192

\title{
DEMONSTRATION OF A SOLUTION FILM LEAK TEST TECHINIQUE AND EQUIPMENT FOR THE S00645 \\ CANISTER CLOSURE (U)
}

\author{
GARY R. CANNELL
}


DOCUMENT: $\quad$ WSRC-TR-99-00192

TITLE:

DEMONSTRATION OF A SOLUTION FILM LEAK TEST TECHNIQUE AND EQUIPMENT FOR THE S00645 CANISTER CLOSURE (U)

APPROVALS

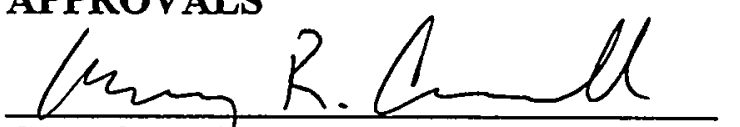

DATE: $9 / 3 / 99$

G. R. Canneli, PREPARER

WELD ENCINEERING

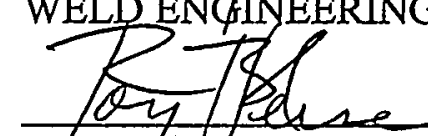

R. B. Heise, SYSTEM ENGINEER

DWRF- ENGHYEZRPAG

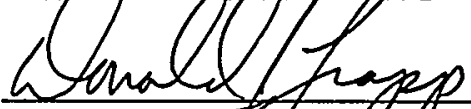

D. J. Trapp, If XK TaE ENGINEER

DATE: $9 / 3 / 99$

NDE SYSTEMS

C. E. Sessions, MANAGER

DATE: $9 / 7 / 9 q$

WELD ENGINEERING

J. W. Ray, WASTE ACCEPTANCE

DATE: $\quad 9 / 7 / 99$

DWPF-ENGINEERING 
WSRC-TR-99-00192

Page iii

\section{CONTENTS}

INTRODUCTION

TECHNIQUE DESIGN AND TEST EQUIPMENT

DEMONSTRATION 2

DISCUSSION 2

CONCLUSIONS 2

REFERENCES 3

ATTACHMENTS 4
PAGE

1

1

2

2

3 
FIGURES

1 Vacuum Box for DWPF Nozzles

2 Specially Prepared DWPF Test Nozzle

3 Test Equipment, Setup and Vacuum Box

$4 \quad$ Vacuum Box Fitted to Test Nozzle

\section{PAGE}

5

6

7

8 


\section{DEMONSTRATION OF A SOLUTION FILM LEAK TEST TECHNIQUE AND EQUIPMENT FOR THE S00645 CANISTER CLOSURE (U)}

\section{INDTRODUCTION}

Canister S00645 nozzle was damaged during processing preparatory to closure welding such that routine closure, using the DWPF Welder (resistance upset welding process), is not feasible ${ }^{1}$. A repair plan has been devised to accomplish the final closure using an alternate welding process ${ }^{2}$. A key step in this plan is leak testing of the final closure - the weld must be verified to meet the Waste Acceptance Product Specifications (WAPS) leaktight criterion of $1 \times 10^{-4} \mathrm{~atm}-\mathrm{cc} / \mathrm{sec}$ helium $^{3}$.

Solution film testing (SFT) has been selected for verifying leaktight integrity of the Canister S00645 final closure. This paper reports the demonstration, as requested by TTR \#HLW/ DWPF/TTR-99030 ${ }^{4}$, of a solution film test technique capable of detecting the WAPS leaktight acceptance criterion when applied to a DWPF canister nozzle. This work meets requirements of Task Technical and Quality Assurance-Plan Number SRTMTS-99-5004, written in accordance with DOE/RW-0333P criteria.

\section{TECHNIQUE DESIGN AND TEST EQUIPMENT}

The solution film test technique (thin-film liquid application) follows the test method specified in ASTM E 515-95, "Standard Test Method for Leaks Using Bubble Emission Techniques"6. E 515 identifies this method to be sensitive to the limit of $1 \times 10^{-5} \mathrm{~atm}$ $\mathrm{cm}^{3} / \mathrm{s}$. This technique also meets requirements specified in ASME Section V, Article 10, Appendix II, "Bubble Test, Vacuum Box Technique"7.

In addition to the general requirements of $\mathrm{E} 515$, several critical parameter values were identified to maximize sensitivity of the technique while retaining ability to visually detect leakage. These parameters include detection fluid (solution), pressure differential (partial vacuum below atmospheric pressure) and test area surface cleanliness. Site Procedure LT-VB ${ }^{8}$ (Bubble test, vacuum box examination), as amended by the specific parameter stipulations identified in Attachment 1, was used for the demonstration testing.

Procedures and personnel utilized in this demonstration were qualified/certified in accordance with standard site quality requirements. Test equipment, gauges, etc., conformed to site calibration (M\&TE) standards.

Solution film test equipment consists of a vacuum box, designed specifically to fit a DWPF canister nozzle, vacuum pump, hose and gauge (Figure 1). 


\section{DEMONSTRATION}

Preparatory to testing, a welded DWPF test nozzle was modified by capping the neck (to facilitate testing) and installing an Accu-Flow ${ }^{9}$ Calibrated leak into the weld plug (Figure 2). The capillary leak, as procured, was set to leak at a rate of $7.5 \times 10^{-5} \mathrm{~atm}-\mathrm{cc} / \mathrm{sec}$ helium. After installation, the test nozzle (capillary leak) was checked using the HighPressure Lab helium mass spectrometer leak detector to confirm the leak rate. The rate of the installed leak was $4.7 \times 10^{-5} \mathrm{~atm}-\mathrm{cc} / \mathrm{sec}$ helium - within the manufacturers stated tolerance. Figure 3 shows the test equipment and setup used for the demonstration.

Having established a leak rate less than the WAPS acceptance criterion, the test nozzle was fitted with the vacuum box and tested using the SFT method (Figure 4). At a vacuum pressure of 24 inches $\mathrm{Hg}$, a continuous stream of small bubbles was visually obseryed in the detection fluid, demonstrating the ability to detect leaks smaller than the WAPS criterion. The test nozzle was then re-checked the following day, in the presence of DWPF-Engineering and SRTC QA personnel - results were identical.

Attachment 2 provides a detailed account of the demonstration testing. Attachment 3 is the solution film leak test report (data sheet). Attachment 4 is the helium leak test data sheet certifying the rate of the prepared leak $-4.7 \times 10^{-5} \mathrm{~atm}-\mathrm{cc} / \mathrm{sec}$ helium.

EES Job Folder, number 22727 (located in 730-A, Document Control) contains pertinent information associated with this demonstration, including equipment calibration documents, test procedures, etc.

\section{DISCUSSION}

The purpose of this effort was to demonstrate that the SFT technique, when adapted to a DWPF canister nozzle, is capable of detecting leaks not meeting the WAPS acceptance criterion.

The ASTM E 515 standard indicates that solution film testing does not provide a quantitative measure of leak rate, but can identify or disclose leaks. In other words, it performs a "pass/fail" function. Sensitivity of SFT testing depends on several factors, but primarily is influenced by detection fluid type, pressure differential across the work piece and test area cleanliness. By following specified procedural requirements, e.g., use of certified materials, certified personnel, maintaining temperature lirnits, and use of an appropriate detection fluid and test pressure differential, SFT is capable of detecting leaks in the $10^{-5} \mathrm{~atm}-\mathrm{cc} / \mathrm{sec}$ helium range.

\section{CONCLUSIONS}

o The SFT technique and equipment described herein, successfully detected a confirmed leak of $4.7 \times 10^{-5} \mathrm{~atm}-\mathrm{cc} / \mathrm{sec}$ helium. This demonstrates the ability to disclose 
a leak in DWPF canister closure welds not meeting the WAPS leak tight acceptance criterion of $1 \times 10^{-4} \mathrm{~atm}-\mathrm{cc} / \mathrm{sec}$ helium.

- Conditions and environment expected (test piece cleanliness, visual access to test area, lighting, etc.) for testing of the S00645 closure weld, should not be significantly different from that encountered in this demonstration effort.

- This SFT technique and equipment can be applied to other DWPF canister closure welds requiring leak testing to satisfy WAPS acceptance criteria.

\section{REFERENCES}

1. NCR No. 97-NCR-05-0122, Canister Waste Form \#S00645 (UJ), 10/1/1997

2. Kerley, W.D. and Heise, R.B., Implementation Plan for Canister S00645 (U), HLWDEN-98-0374, 1/13/1999

3. U.S. Department of Energy Office of Environmental Management, Waste Acceptance Product Specifications for Vitrified High-Level Waste Forms, Revision 2, December 1996

4. Technical Task Request, Number HLW/DWPF/TTR-99030, Revision 1, Provide Sensitivity Findings for Vacuum Box to be Used on Canister S00645 Weld, May 24, 1999

5. Task Technical and Quality Assurance Plan, Number SRT-MTS-99-5004, Revision 0, Demonstration of a Solution Film Leak Test Technique and Equipment for DWPF Canister Closure Welds, July 1999

6. American Society for Testing and Materials, Number E 515-94, Standard Test Method for Leaks Using Bubble Emission Techniques

7. ASME Boiler and Pressure Vessel Code, Section V, Nondestructive Examination, 1998 Edition

8. Bechtel Savannah River, Inc. Nondestructive Examination Standard, Number LT-VB, Revision 4, May 25, 1994

9. "Accu-Flow Calibrated Leak", Manufactured by Vacuum Technology Inc., Oak Ridge, TN 
WSRC-TR-99-00192

Page 4

\section{ATTACHMENTS}

1. Stipulations for Using Procedure LT-VB on DWPF Canister and Test Nozzle Closure Welds

2. Detailed Account of Demonstration Testing

3. IES Solution Film Leak Test Report

4. IES Proof/Leak Test Data Sheet 


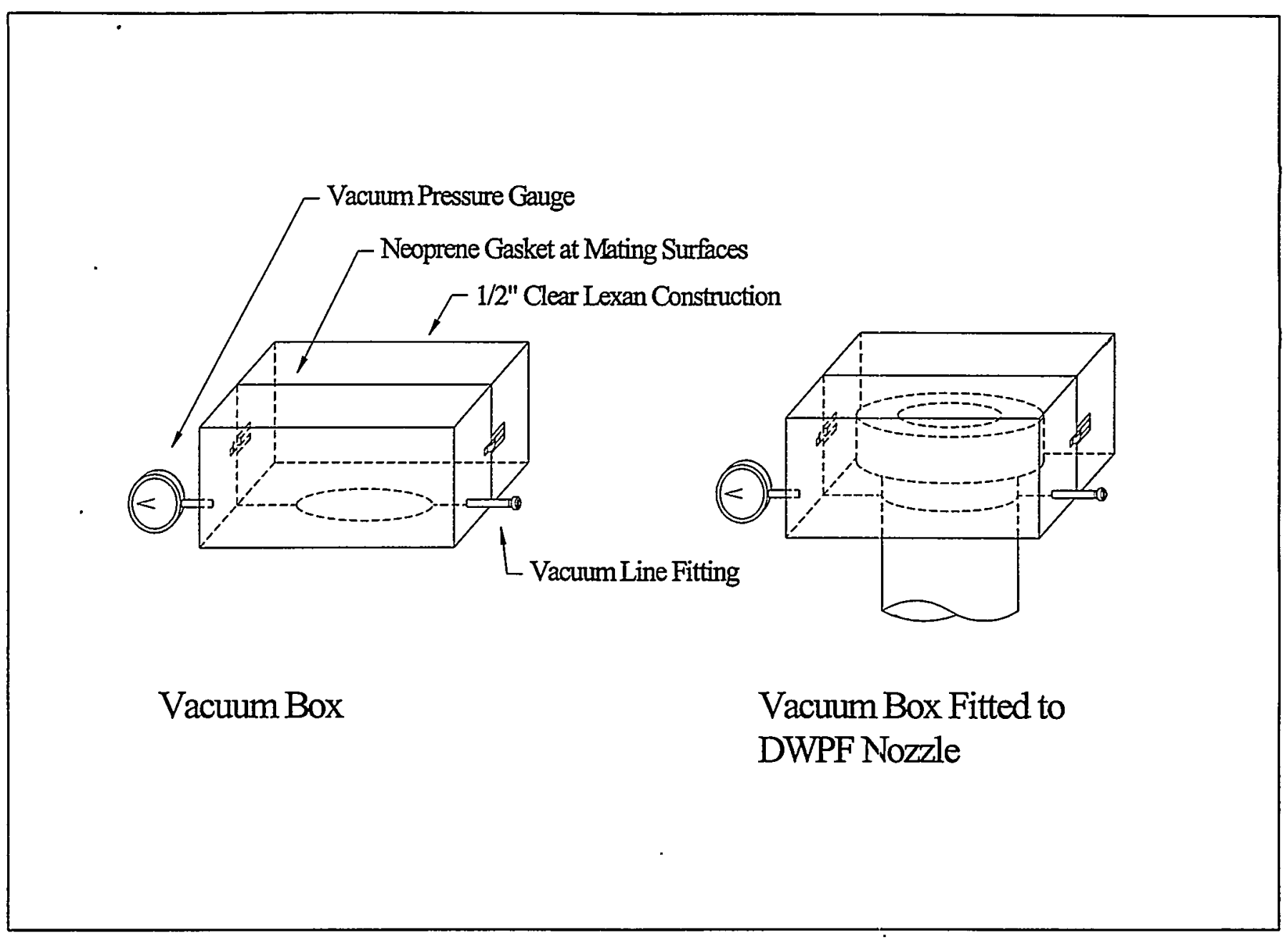

Figure 1. Vacuum Box for DWPF Nozzles 


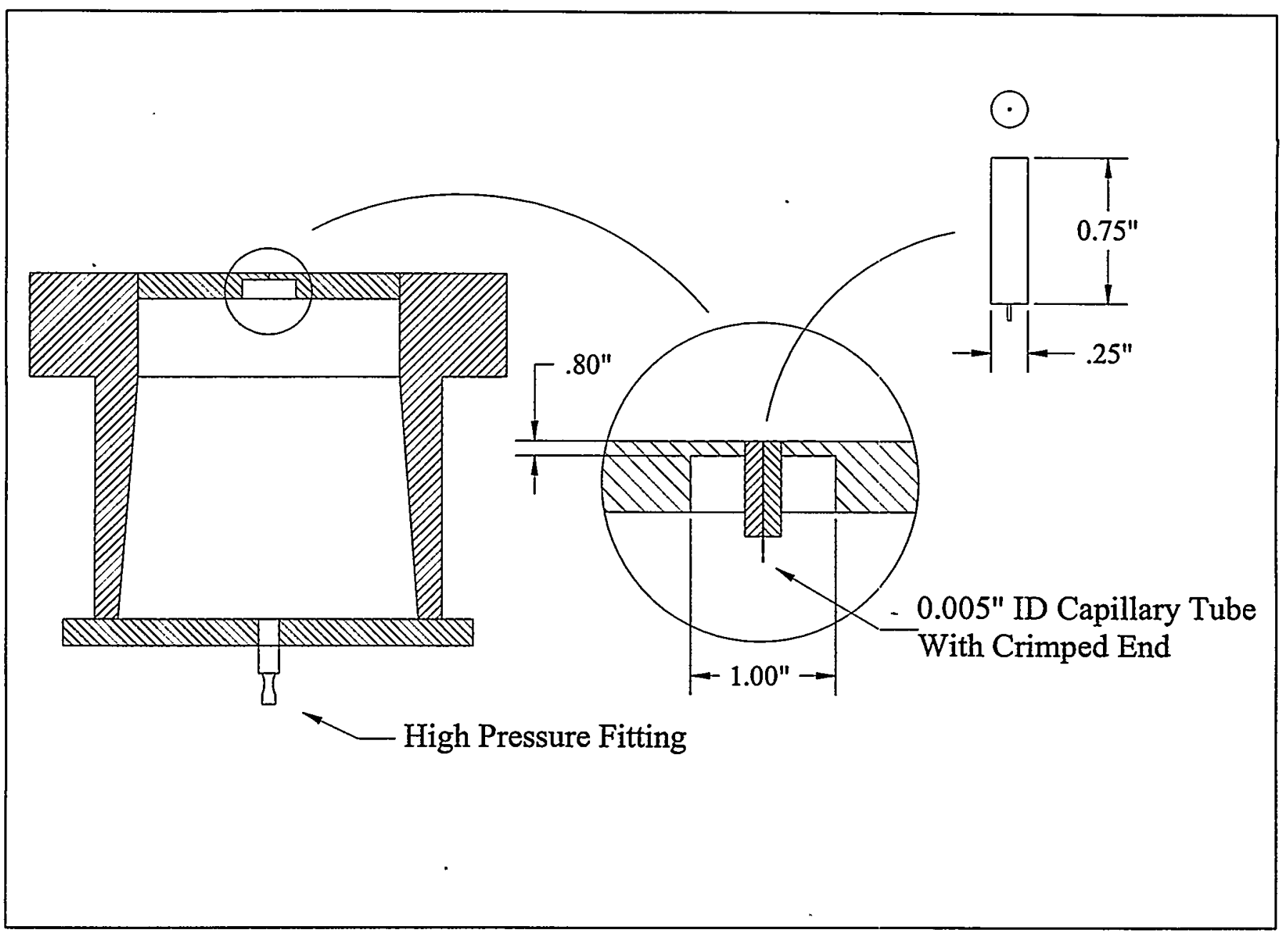

Figure 2. Specially Prepared DWPF Test Nozzle 


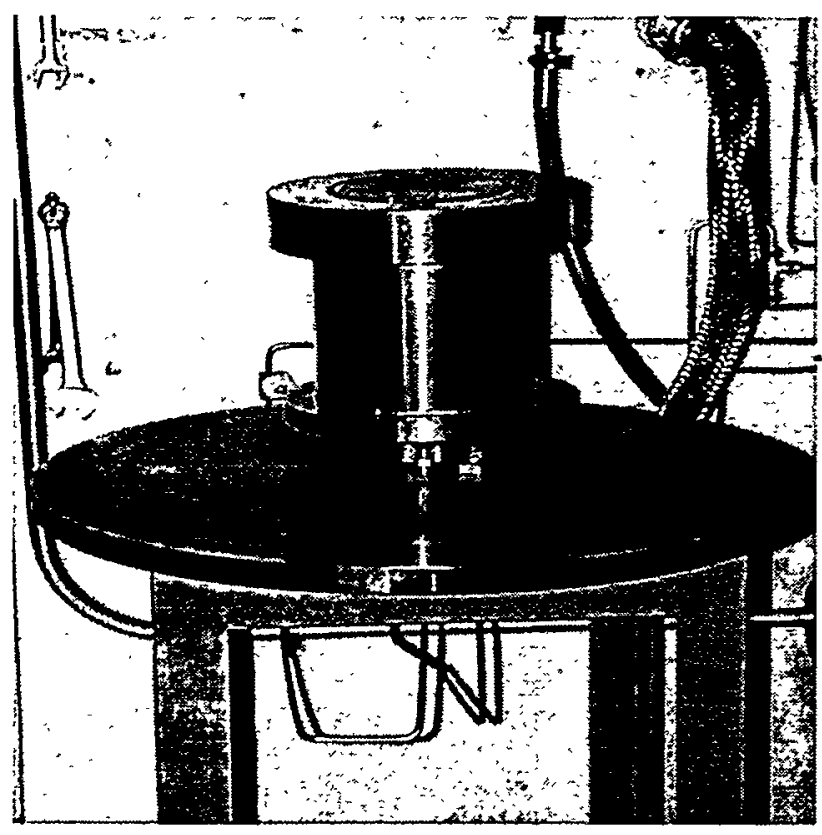

a) Test nozzle connected to helium leak detection unit

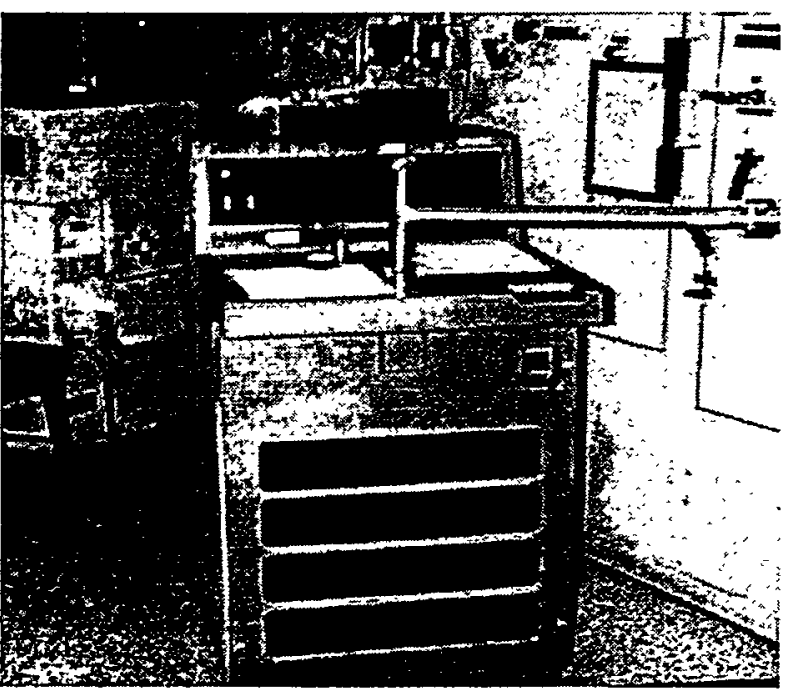

c) Helium leak detection unit

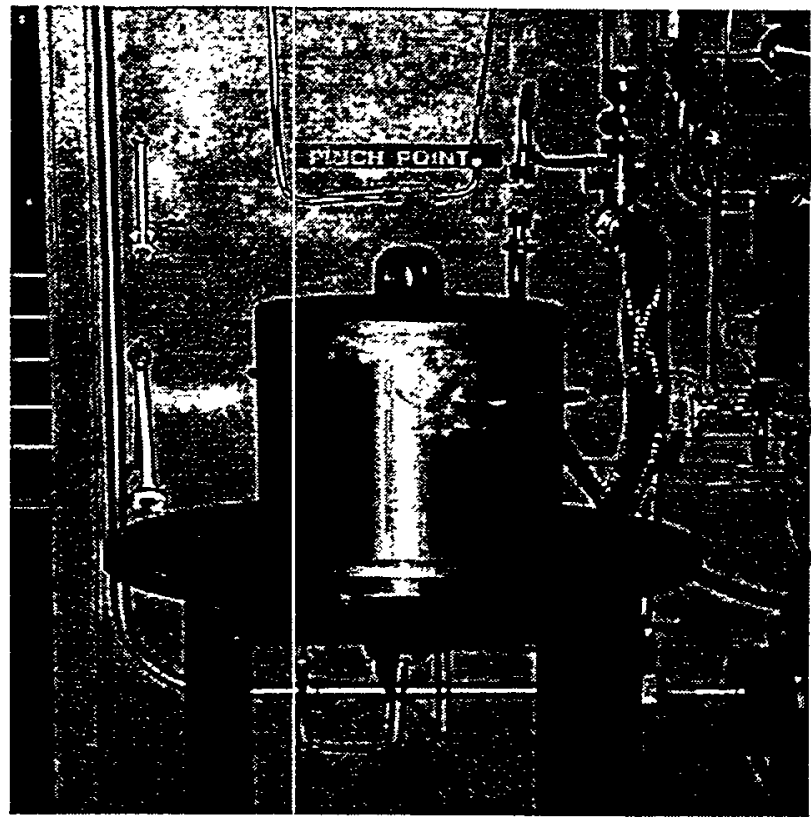

b) Bell jar fitted over test nozzle ready for pump down of bell-jar

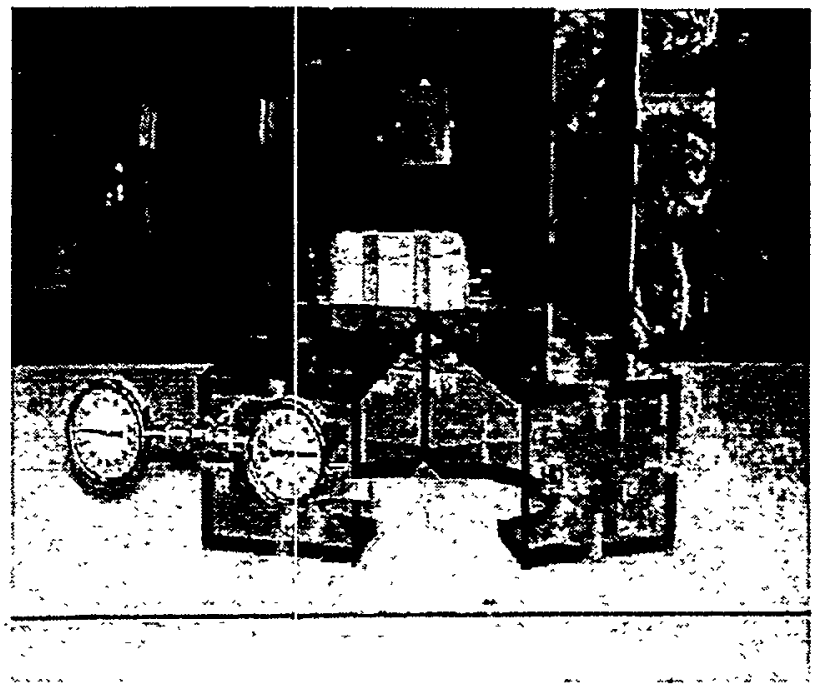

d) Vacuum box designed to solution film test DWPF nozzles

Figure 3. Test Equipment, Setup and Vacuum Box 


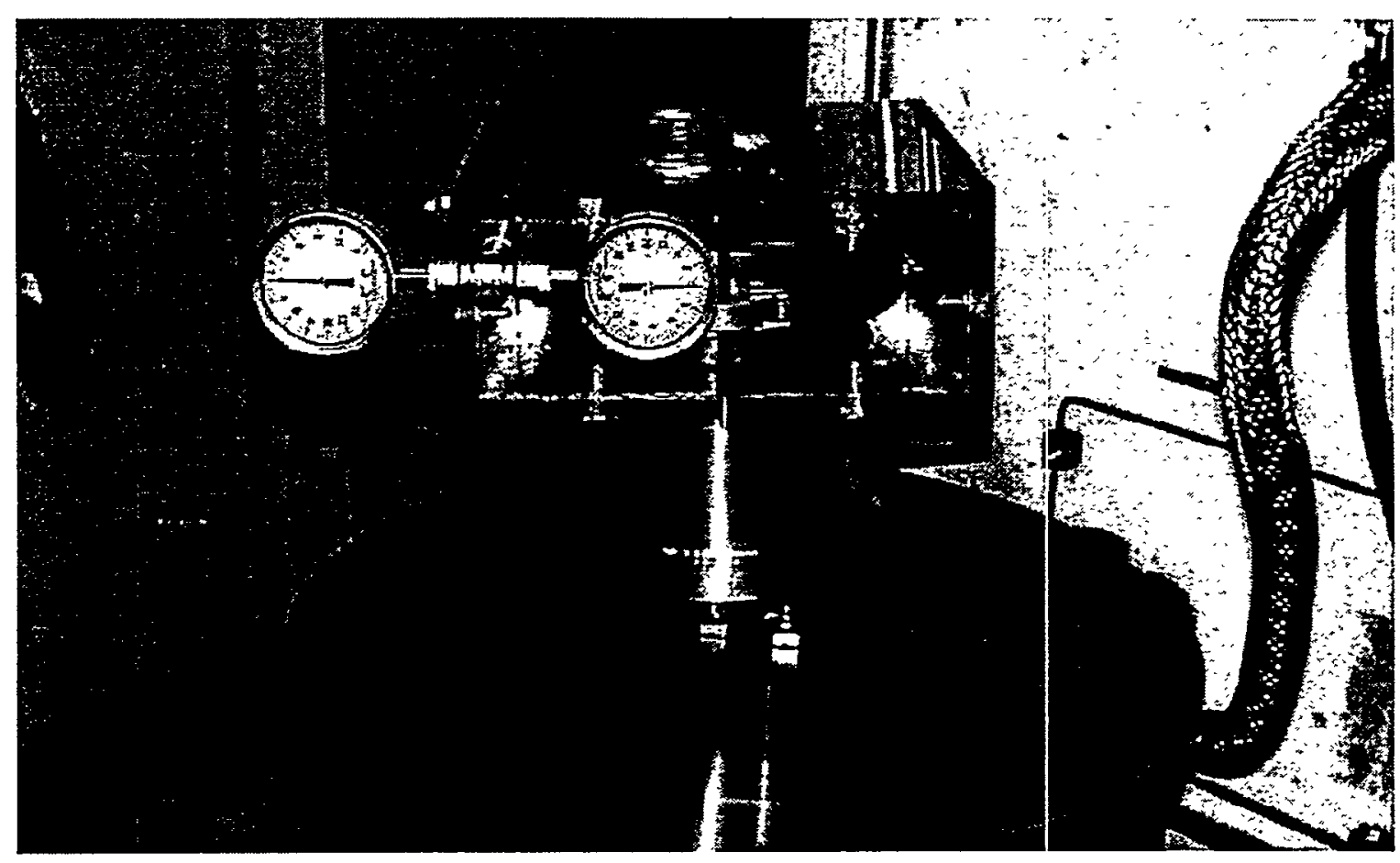

Figure 4. Vacuum Box Fitted to Test Nozzle 


\section{ATTACHMENT 1 \\ Stipulations for Using Procedure LT-VB \\ on DWPF Canister and Test Nozzle Closure Welds}

Scope: The following stipulations shall be observed when solution-film testing DWPF canister and test nozzle closure welds using procedure "BSRI Nondestructive Examination Standard, Vacuum Box, LT-VB", Revision 4, Dated 5/25/94.

General:

1. The term BSRI NDE personnel shall mean also WSRC NDE personnel.

2. The term BSRI NDE procedures and documents shall include also equivalent WSRC procedures and documents.

3. Use attached "IES Solution Film Leak Test Report" to record pertinent test information.

4. Visual observation for bubbles (detection fluid under test) shall be aided by the use of a flashlight and $5 \mathrm{X}$ magnification lens.

Specific:

1. Refer to paragraph 4.1.3: Partial vacuum pressure shall be at least 24 inches $\mathrm{Hg}$ minimum below atmospheric pressure.

2. Refer to paragraph 4.2.1: Bubble solution shall be Leaktec. (American Gas and Chemicals, Inc.), Type OX-315 I.

3. Refer to paragraph 5.4: Immediately prior to application of the bubble solution, the test area shall be rinsed with alcohol and wiped dry with a clean, dry cloth.

4. Refer to paragraph 6.4: With regard to lighting, the following applies: Ambient or artificial illumination shall be considered sufficient when the 1/32 inch graduations on a machinist scale can be resolved at a distance of 24 inches.

5. Refer to paragraph 6.6: The formation of continuous, single small bubbles shall be considered relevant. 
ATTACHMENT 2

Detailed Account of Demonstration Testing

Date: August 4, 1999

Place: High Pressure Lab, 723-A

Equipment:

Helium Mass Spectrometer Leak Detection Unit, Make: Varian, Model: 948

Vacuum box designed specifically to test DWPF nozzles

Examiner Certification:

ASNT SNT-TC-1A

Wayne Thompson, Level II (Mass Spectrometer and Bubble Leak Testing)

Procedures:

Mass Spectrometer Testing: L94-8303, Revision 6 "Leak Testing"

Solution Film Testing: $\quad$ LT-VB, Revision 4 "Nondestructive Examination

Standard, Vacuum Box"

1. Prior to this demonstration, a DWPF test nozzle was modified by capping the neck (to facilitate testing) and installing, by welding, an Accu-Flow Open Style Calibrated leak (crimped capillary tube) through the center of the weld plug. The Vendor specified target leak rate of the capillary leak was $7.5 \times 10^{-5} \mathrm{~atm}-\mathrm{cc} / \mathrm{sec}$ helium.

2. The prepared test nozzle was connected to the Mass Spectrometer unit (helium leak tester) and a leak rate of $4.7 \times 10^{-5} \mathrm{~atm}-\mathrm{cc} / \mathrm{sec}$ helium was recorded.

Note: Immediately prior to and after helium leak testing the nozzle, calibration of the helium leak tester was verified by checking against a kriown standard.

3. The nozzle (immediate area of the installed leak) was wiped down using a clean cloth and alcohol. Detection fluid was applied to the test area and the vacuum box placed on the nozzle and checked for leaks.

4. Within a few seconds, at a vacuum pressure of 24 inches $\mathrm{Hg}$, a continuous stream of tiny bubbles was observed at the leak site. Bubbles were visible with the unaided eye; however, use of a flashlight and magnification lens (5X) significantly improved ability to see the bubbles.

5. The vacuum box was then removed and the test area of the nozzle wiped clean with alcohol. The nozzle was placed under a yacuum to avoid exposure to moisture and other condensables so as to preclude plugging of the leak.

6. The next day, August 5, 1999, DWPF-Engineering personnel were invited to the High-Pressure Lab to witness a repeat of the test. Testing was conducted as described above - results were identical to that of the previous day. 
ATTACHMENT 3

Test Date: $8 / 4 / 99$

IES Solution Film Leak Test Report

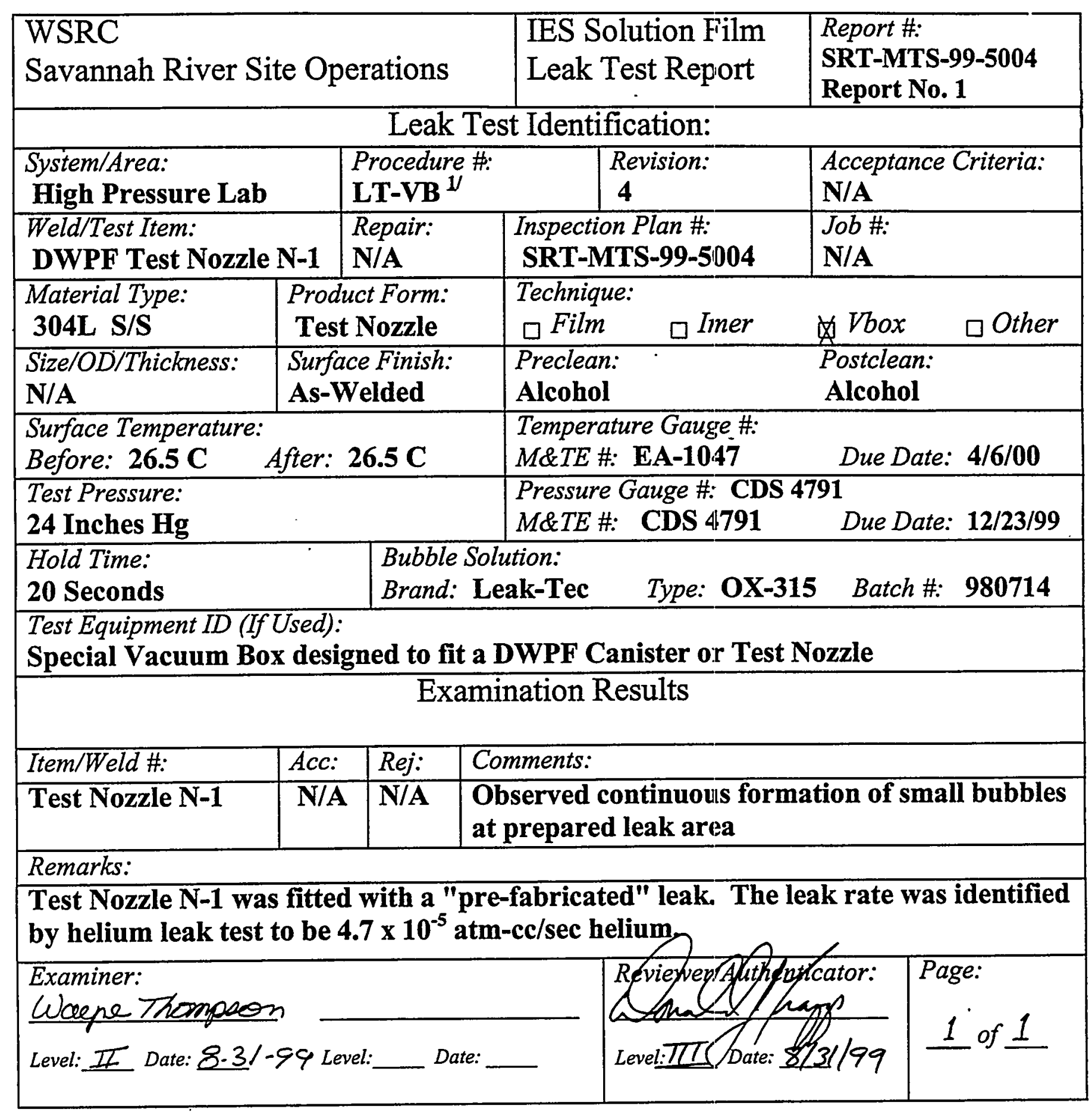

1/ Stipulations in Attachment 6.2, SRT-MTS-99-5004 were applied

General:

- Lighting in demonstration area sufficient to resolve $1 / 32$ inch graduations on a machinist scale at à distance of 24 inches

- Visual examination was aided by use of a flashlight and $5 \mathrm{X}_{\llcorner}$magnification lens 


\section{ATTACHMENT 4 IES Proof/Leak Test Data Sheet}

Attached is the High-Pressure Lab (IES) mass spectrometer helium leak test report certifying the leak rate of the installed leak device in the DWPF test nozzle, N-1. In addition, calculation M-CLC-A-00150, "Verification if IES Proof/Leak Test Software, Version $1.9 "$ is attached. 
$08 / 04 / 99$

PAGE 1 OF 2

Record : 1374
* * ACCEPTABLE ** .

Basis No.: SRT-IES-99-204 RETENTION : LIFE

CC: GARY CANNELL

Laboratory Copy

File Room, 730-A

SRI Records, 773-A

IES PROOF/LEAK TEST DATA SHEET (U)

Test Item: VTI CALIBRATION LEAK

Test Item Serial Number: 06564

Test Date: 08/04/99

Body: Leakage Rate, std cc He/sec: $4.7 \times 10-5$

Proof Pressure (psig): NA

Leak Test Pressure (psig): 1 ATMOS

Acceptable Maximum Leak Rates, std cc He/sec:

Body: $9.0 \times 10-5$

IES Test Engineer: D. J. TRAPP

Phone: $725-8307$

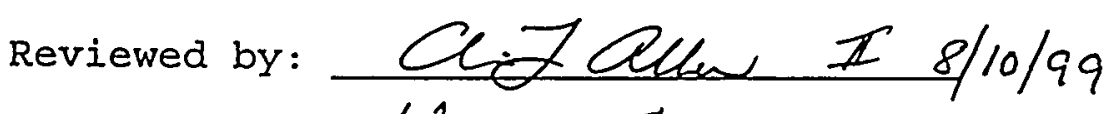

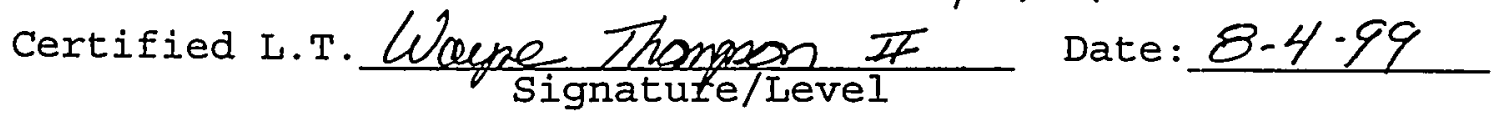

COMMENTS

ACTUAL PROOF TEST PRESSURE NA

ACTUAL LEAK TEST PRESSURE 1 ATMOS.

ACTUAL BURST TEST PRESSURE NA 
PAGE 2 OF 2

Record : 1374

\section{TEST DESCRIPTION}

Technician: WAYNE THOMPSON

Procedure No.: OP:L9.4-8303

Proof Test Time (min):

Revision No.: 7

Leak Test Method: BELI JAR

Proof Test Fluid:

Leak Test Fluid: $\mathrm{HE}$

Leak Test Time (min): 3

$\%$ Concentration: 100

TEST EQUIPMENT

M\&TE Description

Leak Detector

Strip Chart Recorder

Pressure Gauge/Transducer

Thermometer
No.

\begin{tabular}{llll|l} 
& No. & \multicolumn{2}{c}{ Ca.1? } & Expires \\
$\mid$ & $8-1135$ & $\mid \mathrm{Y}$ & $\mathrm{B} / \mathrm{A}$ \\
$\mid$ & 12853 & $\mid \mathrm{N}$ & $\mid \mathrm{NA}$ \\
$\mid$ & $3-1068$ & $\mid \mathrm{Y}$ & $\mid 01-05-00$ \\
$\mid$ & $\mathrm{EA-1047}$ & $\mid \mathrm{Y}$ & $\mid 04-06-00$ \\
$\mid$ & & $\mid$ & $\mid$
\end{tabular}

\section{PRELIMINARY CAIIBRATION}

Preliminary standard Leak Rate, std cc He/sec: $9.61 \times 10-5$ Standard Leak M\&TE \#: 3-1452 Expires: $01 / 22 / 00$ Preliminary Standard Leak Cal. Temp, oc: 26.6 Room Temperature, oC: 23.8 Preliminary Temp Corrected standard Leak Rate, std CC He/sec: $8.8 \times 10-5$

Preliminary Cal Background, Divisions: 6.5

Preliminary Cal Meter Reading, Divisions: 85000.0

Preliminary Sensitivity (std cc He/sec/Division): $1.0 \times 10-9$

\section{FINAL CALIBRATION}

Final Standard Leak Rate, std CC He/sec: $9.61 \times 10-5$

Standard Leak M\&TE \#: 3-1452

Final Standard Leak Cal Temp, oC: 26.6

Expires: $01 / 22 / 00$

Final Temp Corrected Standard Leak Rate, std CC He/sec: $8.8 \times 10-5$

Final Cal Background, Divisons: 35.0

Final Cal Meter Reading, Divisons: 80000.0

Final Sensitivity (std CC He/sec/Division): $1.1 \times 10-9$

\section{LEAK MEASUREMENTS}

Body Sample Background, Divisions: 6.5

Sample Meter Reading, Divisions: 43000.0 


\section{Calculation Cover Sheet}

\begin{tabular}{|l|l|l|}
\hline $\begin{array}{l}\text { Project } \\
\text { N/A }\end{array}$ & $\begin{array}{l}\text { Calculation Number } \\
\text { M-CLC-A-00150 }\end{array}$ & $\begin{array}{l}\text { Project Number } \\
\text { N/A }\end{array}$ \\
\hline \begin{tabular}{l} 
Title $\begin{array}{l}\text { Verification of IES Proof/Leak Test Software, Version 1.9 } \\
\text { FunctionalClassification } \\
\text { GS }\end{array}$ \\
\cline { 2 - 3 }
\end{tabular} & $\begin{array}{l}\text { Discipline } \\
\text { Mechanical Engineering }\end{array}$ \\
\hline
\end{tabular}

$\square$ Preliminary $\triangle$ Confirmed

Computer Program No.

$\bigotimes N / A$

Version/Release No.

Purpose and Objective

This calculation compares IES Proof/Leak Test Software, Version 1.9 leak test results wilh manual calculations per IES Procedure L9.4-8303 Rev. 7, Section 5.5.1.

The IES Proof/Leak Test Software, Version 1.9 calculates leak test results correctly as desscribed in IES Procedure L9.4-8303 Rev. 7. Section 5.5.1.

\begin{tabular}{|c|c|c|c|c|}
\hline & \multicolumn{4}{|c|}{ Revisions } \\
\hline $\begin{array}{l}\text { Rev } \\
\text { No. }\end{array}$ & \multicolumn{4}{|l|}{ Revision Description } \\
\hline$\not$ & Divitu' sisce & & & \\
\hline \multicolumn{5}{|c|}{ - } \\
\hline \multicolumn{5}{|c|}{ Sign Off } \\
\hline $\begin{array}{l}\text { Rev } \\
\text { No. }\end{array}$ & Originator (Print) Sign/Date & Verification/ Checking Method & Verifier/Checker (Print) Sign/Date & Manager (Print) Sign//Date \\
\hline$\phi$ & Dopalas d Teapp $8 / 10 / 99$ & $\begin{array}{l}\text { DOCUMENT } \\
\text { REVIEU }\end{array}$ & 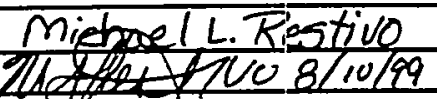 & 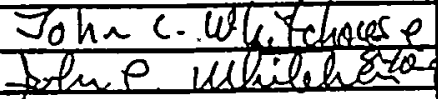 \\
\hline & 70 & & & \\
\hline & & & & \\
\hline \multicolumn{5}{|c|}{$\begin{array}{l}\text { Classification } \\
\text { Unclassified }\end{array}$} \\
\hline
\end{tabular}




\section{Calculation Continuation Sheet}

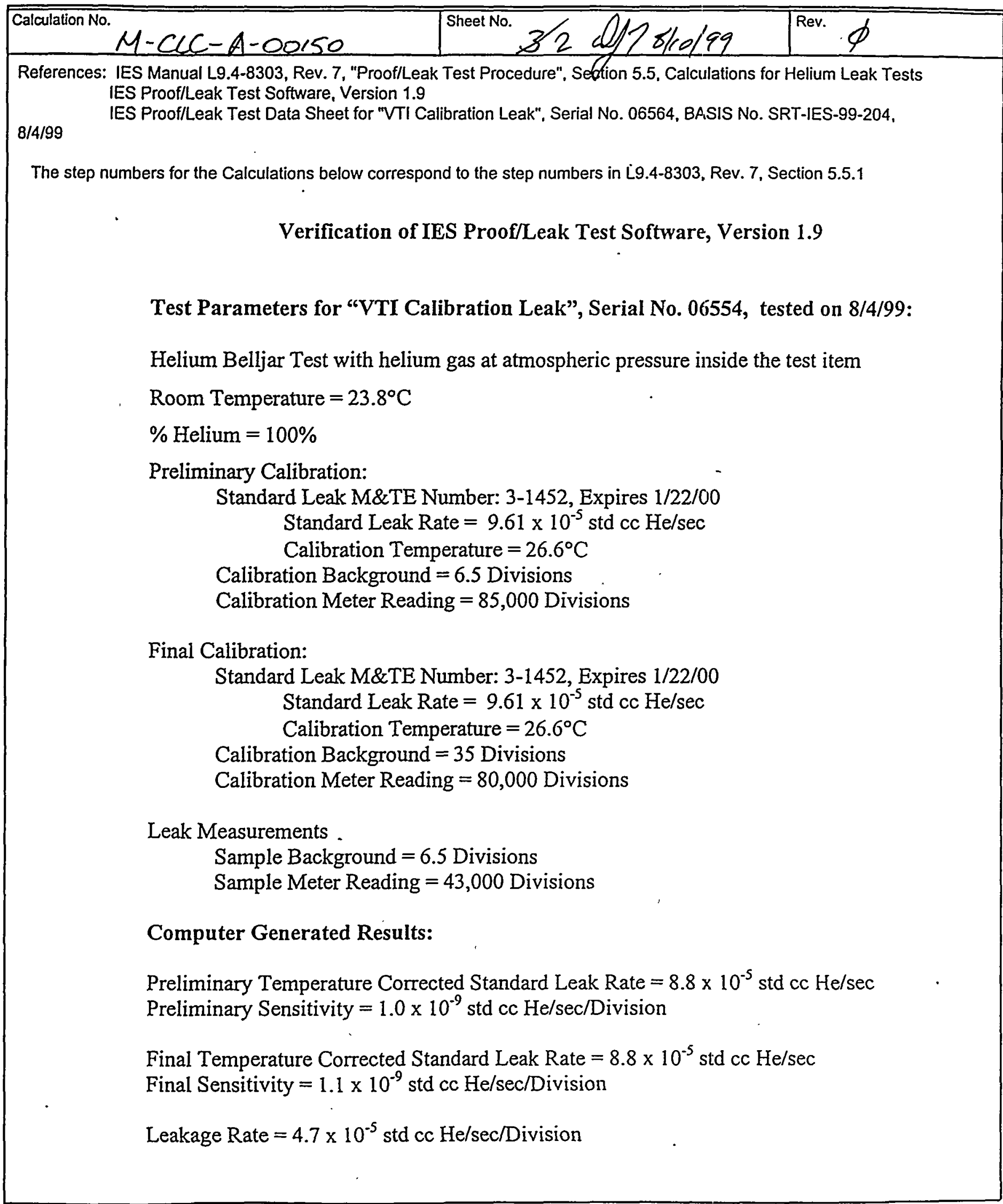




\section{Calculation Continuation Sheet}

\begin{tabular}{|c|c|c|}
\hline Calculation No. & Sheet No. $2 C-A-00150$ & Rev.
\end{tabular}

\section{Manual Calculations .}

A. Temperature Correction Factor (For Both Preliminary and Final Calibrations)

$$
C L=C-\left[\left(T_{c}-T_{r}\right) * .03 * C\right]
$$

$\mathrm{CL}=$ Actual Calibration Leakage Rate

$\mathrm{C}=$ Stated Leakage rate of Calibrated Leak $=9.61 \times 10^{-5} \mathrm{std} \mathrm{cc} \mathrm{He} / \mathrm{sec}$

$\mathrm{Tc}=$ Temperature at which calibrated leak was calibrated $=26.6^{\circ} \mathrm{C}$

$\dot{\mathrm{T}} \mathrm{r}=$ Room Temperature $=23.8^{\circ} \mathrm{C}$

$C L=9.61 e^{-5}-\left[(26.6-23.8) * .03 * 9.61 e^{-5}\right]=8.80 e^{-5}$ std $\mathrm{cr} \mathrm{He} / \mathrm{sec}$

This matches the computer results.

B. Preliminary Calibration

$$
\begin{gathered}
P C L R=\frac{C L^{\circ}}{(M R-B G)} \\
\mathrm{PCLR}=\text { Preliminary Test Sensitivity } \\
\mathrm{CL}=\text { Actual Calibration Leakage Rate }=8.8 \times 10^{-5} \mathrm{std} \mathrm{cc} \mathrm{He} / \mathrm{sec} \\
\mathrm{MR}=\text { Meter Reading with calibrated leak opened to the leak detector }= \\
\quad 85,000 \text { Divisions } \\
\mathrm{BG}=\text { Meter Reading after calibrated leak has been closed }=6.5 \text { Divisions }
\end{gathered}
$$

$$
\text { PCLR }=\frac{8.8 e^{-5}}{(85000-6.5)}=1.03 e-9 \mathrm{std} \mathrm{cc} \mathrm{He} / \mathrm{sec} / \text { Division }
$$

This matches the computer results of $1.0 \times 10^{-9} \mathrm{std} c \mathrm{He} / \mathrm{sec} / \mathrm{Division}$ for Preliminary Sensitivity. 


\section{Calculation Continuation Sheet}

\begin{tabular}{|c|c|c|}
\hline Calculation No. $M-C C C-A-00150$ & Sheet No & Rev. \\
\hline
\end{tabular}

C. Final Calibration

$$
\begin{gathered}
A C L R=\frac{C L}{(M R-B G)} \\
\mathrm{ACLR}=\text { Preliminary Test Sensitivity } \\
\mathrm{CL}=\text { Actual Calibration Leakage Rate }=8.8 \times 10^{-5} \mathrm{std} \mathrm{cc} \mathrm{He} / \mathrm{sec} \\
\mathrm{MR}=\text { Meter Reading with calibrated leak opened to the leak detector }= \\
\mathrm{BG}=\text { Meter Reading after calibrated leak has been closed }=35 \text { Divisions } \\
A C L R=\frac{8.000 \text { Divisions }}{(80000-35)}=1.10 e-9 \mathrm{std} \mathrm{cc} \mathrm{He} / \mathrm{sec} / \text { Division }
\end{gathered}
$$

This matches the computer results of $1.1 \times 10^{-9} \mathrm{std} \mathrm{cc} \mathrm{He} / \mathrm{sec} / \mathrm{Division}$ for Final Sensitivity.

D. Measured Leak Rate:

$$
M L R=A C L R^{*}(M R-B G) *(\% H e / 100)
$$

MLR $=$ Measured Leak Rate of the test item

$\mathrm{ACLR}=$.Final test sensitivity $=1.10 \mathrm{e}-9 \mathrm{std} \mathrm{cc} \mathrm{He} / \mathrm{sec} /$ Division

$M R=$ Meter Reading with the test item filled with helium $=43,000$ Divisions

$B G=$ Meter Reading after helium has been vented $=6.5$ Divisions

$\% \mathrm{He}=$ the percent concentration of helium in the tracer gas $=100 \%$

$M L R=1.1 e^{-9} *(43000-6.5) *(100 / 100)=4.73 e-5$ std cc He/sec

This matches the computer results of $4.7 \times 10^{-5}$ std cc He/sec for Leakage Rate. 


\section{Calculation Continuation Sheet}

\begin{tabular}{|c|c|c|}
\hline Calculation No. & Sheet No. $5-A-00150$ & Rev. $\phi$ \\
\hline
\end{tabular}

E. Minimum Detectable Leak

$$
\begin{gathered}
M D L=A C L R * .02 * \text { Full_Scale_Reading_of_Background_Scale } \\
\text { MDL }=\text { Minimum Detectable Leakage Rate } \\
\text { ACLR }=\text { Final Test Sensitivity }=1.10 \mathrm{e}^{-9} \mathrm{std} \mathrm{cc} \mathrm{He} / \mathrm{sec} / \text { Division }
\end{gathered}
$$

Full Scale Reading of the Background Scale: The background for the test was 6.5 divisions. The full scale reading for the leak detector is 10 Divisions.

$$
M D L=1.1 e^{-9} * .02 * 10=2.2 e^{-10} \text { std cc He/sec }
$$

This matches the computer results of $2.2 \times 10^{-10} \mathrm{std}$ cc He/sec for Minimum

Detectable Leak Rate. This number only appears on the computer screen and is not printed out on the datasheet.

F. Reported Leak Rate

Measured Leak Rate $=4.73 \times 10^{-5} \mathrm{std} \mathrm{cc} \mathrm{He} / \mathrm{sec}$

Minimal Detectable Leak Rate $=2.2 \times 10^{-10} \mathrm{std} \mathrm{cc} \mathrm{He} / \mathrm{sec}$

Final Sensitivity $=1.10 \times 10^{-9} \mathrm{std} \mathrm{cc} \mathrm{He} / \mathrm{sec} / \mathrm{Division}$

The Reported Leak Rate is the largest of the three numbers listed above, which would be the Measure Leak Rate $=4.73 \times 10^{-5} \mathrm{std} \mathrm{cc} \mathrm{He} / \mathrm{sec}$.

This matches the computer results, which reports a leak rate of $4.7 \times 10^{-5}$ std cc Helsec.

\section{Conclusion:}

The IES Proof/Leak Test Software calculated the leak test results exactly as specified in L9.3-8303, 5.1. 5.5.1 0)/78/10/99 